\section{Tusind plateauer}

Gilles Delenze \& Félix Guattari: Tusind plateauer. Kapitalisme og skizofreni: Oversat af Niels Lyngso. Det Kongelige Danske Kunstakademis Billed-skoler, 2005, 721 sider, kr. 330,-

I 1980 udkom i Frankrig Mille Plateaux skrevet af filosoffen Gilles Deleuze (1925-1995) og psykoanalytikeren Félix Guattari (1930-1992). Det var andet bind $i$ et tobindsværk med undertitlen Kapitalisme og skizofreni, hvor førstebindet Anti-Ødipus (en kritik af bl.a. 68'ernes Marx-Freud syntese) udkom i 1972. Nu er Tusind plateaner udkommet på dansk, hvilket må siges at være lidt af en litterær-filosofisk sensation og et meget velkomment bidrag til den stadig mere markante Deleuze-læsning herhjemme, der bl.a. tæller bogen Flugtlinier - om Deleuzes filosofi fra 2001.

På dansk findes allerede Forbandlinger 1972-1990 (2006), Foucault (2006), Proust og tegnene (2003), Folden (1991, uddrag), Sacher-Masoch og masochismen: det kolde og det grusomme (1981), Hvad er filosofi? (1996) samt Kafka - for en mindre litteratur (1982), de to sidste skrevet sammen med Félix Guattari. Vi skal heller ikke undlade at gøre opmærksom på, at der i Slagmark nr. 26/1997 er et minitema om Deleuze, hvori der bl.a. er en samtale mellem Deleuze og Antonio Negri. Det nu oversatte værk er både frygtindgydende og indbydende. Det består af 15 uafhængige kapitler eller plateauer, der både kan læses individuelt og som engageret $\mathrm{i}$ en fælles dialog. Læsningen kræver nøje opmærksomhed og en vilje til at lade filosofien inddrage naturvidenskab, mytologi, politik, lingvistik mm i sin arbejds- og fremstillingsform.

Værket er i sin 'form' en illustration af en pointe $i$ bogen, nemlig at sætte systemer under pres, at undergrave deres selvforståelse, at inddrage det, systemerne ikke selv kan tænke. Hvert kapitel har et årstal og en titel, som f.eks. "1914 - en enkelt ulv eller adskillige", "10.000 f.kr. - moralens genealog?", "28. november 1947 - bvordan man laver sig et legeme uden organer", der mere end antyder værkets eklektiske karakter, og hvis mangel på kronologisk fremadskriden inviterer læseren til at gå på opdagelse snarere end at følge den form, som en bog nødvendigvis har, hvor side 123 kommer efter side 122 osv. Dog kan det anbefales at læse indledningen om 'rhizomet' som det første, da en række væsentlige begreber her tematiseres (defineres ville være for stærkt et ord) og udfoldes, og det angives, at den er konciperet $i$ en afstandtagen til en tankegang, hvor "træet har domineret den vestlige virkelighed og hele den vestlige tanke fra botanikken til biologien, anatomien, men også gnoseologien, teologien, ontologien, hele filosofien" (s. 25), der disponerer for en særlig tankemåde domineret af rodstrukturer, skovbeplantning og fældning. Heroverfor stiller de østens forhold til "steppen og havet", dvs. til nomaden og havedyrkeren frem for til skovfogeden og landmanden. 
Disse figurer går igen gennem værket på overraskende, oplysende og forvirrende måder.

Denne anmelder er det sidste halve år gået til og fra værket $i$ en skiftevis begejstring og irritation. Begejstring, fordi der her er en overflod af tanker, indsigter, undergravninger og invitationer til videre arbejde - særligt har jeg fundet kapitlerne om mikropolitik og krigsmaskinen yderst interessante. Men også irritation, da denne særlige form for fransk filosoferen, der undviger klarheden til fordel for formen, ikke passer godt til et utålmodigt temperament.

Oversætteren Niels Lyngsø har gjort en kæmpeindsats. Sproget er flot og flydende, og der er en lang række oversætternoter, der hjælper læseren ind i dette særlige sprogunivers. Desuden har Peter Borum gennemarbejdet og forbedret det generelle noteapparat, bl.a. med henvisninger til danske udgaver af refereret litteratur samt udarbejdet to fyldige registre, der ikke var at finde i originalversionen. Det skal desuden bemærkes, at bogens design - gult omslag med rød skrift - er lækkert og indbydende, hvilket lokker læseren ind i denne bog, der ellers skræmmer ved sin længde og tyngde. Hvis man undrer sig over, hvorfor Det Kongelige Danske Kunstakademis Billedskoler har udgivet den, så får man en del af forklaringen $i$ et efterord af billedhuggeren og professor ved Billedhuggerskolen, Henrik B. Andersen.

Hvis vi afslutningsvis skal lege lidt med undertitlen, så må denne udgivelse siges at udtrykke et skizofrent forhold til kapitalistisk profitmaksimering - og tak for det.

Mikelel Thorup

\section{Kritik}

Henrik Kaare Nielsen \& Finn Horn: Kritike som deltagelse. Klim, 2006, 243 sider, kr. 269,-

Denne bog kan på mange måder betragtes som et opråb. Et opråb fra et videnskabeligt og journalistisk fællesskab, som føler sig klemt under de nuværende politiske strømninger. Og vel at mærke et videnskabeligt og journalistisk fællesskab, som meget vel fornemmer, at en vigtig kilde til dette pres kommer fra den videnskabelige og journalistiske praksis selv. På denne måde giver det god mening at karakterisere bogen som selvrefleksiv. Men det udarter aldrig til selvcentreret navlepilleri, idet selvrefleksionen hele tiden er initieret af en spørgen til og undren over det nuværende politiske hegemoni.

Anstødsstenen er den 'kulturkamp' og 'værdidebat' som den nuværende regering (stærkt understøttet af partiet Dansk Folkeparti) med megen succes har slået sig op på. Den grundlæggende diagnose er, at der herved er opstået et retorisk hegemoni, hvor det er vanskeligt at trænge igennem med en modstand, der ikke fra starten vil være diskvalificeret. Og ærin- 